\title{
Accidental Exposure to Blood and Biological Products in a Tertiary Teaching Hospital in Romania
}

\author{
ERZSEBET KALMAN ${ }^{1,2 *}$, AMANDA RADULESCU ${ }^{3}$, ANDREEA HANGANUT ${ }^{3}$, \\ CRISTINA BORZAN ${ }^{1}$ \\ ${ }^{1}$ Iuliu Hatieganu University of Medicine and Pharmacy, Faculty of Medicine, Public Health and Management Department, \\ 8 Victor Babes Str., 400012, Cluj-Napoca, Romania \\ ${ }^{2}$ Regional Institute of Gastroenterology and Hepatology Prof. Dr. Octavian Fodor, 5 Constanta Str., 400158, Cluj-Napoca, \\ Romania \\ ${ }^{3}$ Iuliu Hatieganu University of Medicine and Pharmacy, Faculty of Medicine, Epidemiology Department, 8 Victor Babes \\ Str., 400012, Cluj-Napoca, Romania
}

Abstract. Disclosure of the announcement rate of occupational exposure to blood and other biological fluids and the compliance rate for post exposure prophylaxis and monitoring measures among employees of the Regional Institute of Gastroenterology-Hepatology "Prof. Dr. Octavian Fodor" Cluj-Napoca. A prospective study was conducted between 2011-2016. All the hospital employees were included in the study. Descriptive analysis of reported cases of exposure to biological products was performed. Considering the number of employees and professional categories throughout the years of study, there was reported a very small number of accidents due to biological sample exposure, compared to statistical data. We have assessed the compliance of the exposed medical staff to postexposure monitoring protocol, which was very low.

Keywords: exposure reporting, biological products, health care workers, compliance, HBs post-vaccine antibodies

\section{Introduction}

This study is part of a PhD research with the title of "The study of production conditions and the predisposing factors in the accident with exposure to biological products of healthcare personnel". The HCW could be exposed to blood and other biological products from the assisted patients during performing their professional activity. These occupational exposures should be reported in order to apply the post-exposure prophylaxis, necessary to minimize the transmission risk for bloodborne pathogens like hepatitis B virus (HBV), hepatitis C virus (HCV) and human immunodeficiency virus (HIV). Our first assumption was the existence of a sub-reporting among the health care workers (HCW) of different occupational exposure to blood and other biological products. A low compliance for post-exposure prophylaxis measures was also observed [1-3]. Moreover, these undesirable events should advocate for the employers to implement the use of sharp objects (needles, scalpels) fitted with a protective system $[6,9]$.

Our second assumption was the fact that the anti-hepatitis B vaccine offers protection (protective level of antibodies $\geq 10 \mathrm{mIU} / \mathrm{mL}$ ) to $\geq 90 \%$ of those vaccinated.

\section{Materials and methods}

The study was conducted for a period of 6 years, between 2011-2016 and led to the database fulfillment of the Health Care Associated Infections Prevention and Control Department in "Prof. Dr Octavian Fodor "Regional Institute of Gastroenterology - Hepatology, Cluj - Napoca, Romania (universitary tertiary hospital with 410 beds, a mean of 17700 hospital admissions per year and a mean of 856 employees per year). The data was collected in a prospective longitudinal way by recording

\footnotetext{
*email: elikalman@yahoo.com
} 
them in the „Register of accidental occupational exposure to biological products”, completed based on chronological reporting of the exposure events by the employees of the medical unit. The study includes two parts.

In the first part of the study the recorded and processed data were: the profile of the department, the time of the day when the event occurred, the occupational category (doctor, nurse, housekeeping personnel etc), the age, gender, the vaccine status for hepatitis B of the injured HCW (healthcare worker), the production mechanism and the medical maneuvre involved in the occurrence of the accident, the patient carrier state regarding HBV, HCV, HIV and submission to postexposure tests, when appropriate.

A postexposure monitoring protocol was established according to effective legislation and guidelines [7]. In the case of a positive source for HBV, HCV or HIV the recommendations included the testing of the person who reported the accident at 6 weeks, 3 and 6 months post-exposure for the incriminated virus, or stopping the follow up if the source was negative. If the source was unknown, standard precautions were applied, considering the source possibly infected with all the three viruses.

The second part of the investigation was a comparative study based on two groups of subjects. In the first group were selected 16 subjects, the inclusion criteria being a positive or unknown source of HBV or a complete history of anti-hepatitis B vaccination (confirmed) or having an uncertain vaccination (declarative only). An arbitrary control group of 17 subjects was randomly selected from those with complete or uncertain vaccine history, but with negative HBV exposure. A quantitative testing of HBs post-vaccine antibodies (HBsAb) and a comparison of the percentage of individuals with protective titre ( $\geq 10 \mathrm{mUI} / \mathrm{ML}$ ) in the two groups, but also with data provided by the World Health Organization was suggested for both groups. [20]

The data base establishment and data processing has been completed using Excel 2010 program. In the first part of the study, data analysis was performed by statistical and mathematical methods (calculation of frequencies, averages). In the second part of the study, the Chi-square association test (2x2) was used.

\section{Results and discussions}

In the sanitary unit under study, 107 cases of exposure to blood or biological products were reported and recorded between 2011-2016 (Figure 1.).

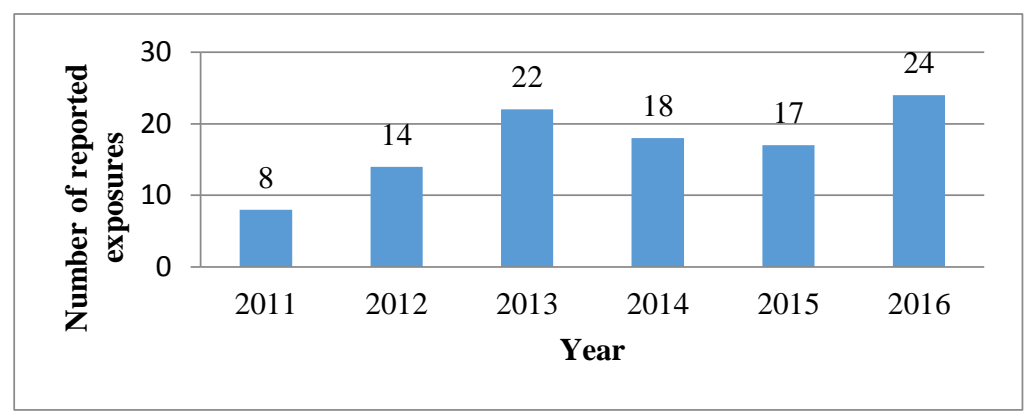

Figure 1. Yearly distribution of newly recorded cases

Analysis of these data by occupational categories, acknowledged (revealed) that nurses reported most frequently the presence of exposure. Laboratory staff with higher education level (biologists, chemists), did not report any occupational exposure. Students reported only four accidental exposures during the study period. The data are presented in table 1 . 
Table 1. The number of exposures registered by occupational category, related to the number of employees in 2011-2016

\begin{tabular}{|c|c|c|c|c|c|c|c|c|}
\hline & Occupational category & $\begin{array}{c}\text { Medical } \\
\text { doctors, } \\
\text { Consultants }\end{array}$ & $\begin{array}{l}\text { Resident } \\
\text { doctors }\end{array}$ & $\begin{array}{l}\text { Biologists, } \\
\text { chemists, } \\
\text { physicists }\end{array}$ & $\begin{array}{c}\text { Nurse, } \\
\text { technicians, } \\
\text { kinetotherapists }\end{array}$ & $\begin{array}{l}\text { Caregivers, } \\
\text { housekeepers, } \\
\text { stretcher- } \\
\text { bearers }\end{array}$ & Total & Students \\
\hline \multirow[t]{3}{*}{2011} & Number of employees & 70 & 432 & 11 & 251 & 141 & 905 & Variable \\
\hline & $\begin{array}{c}\text { Reported occupational } \\
\text { exposures }\end{array}$ & 1 & 1 & 0 & 6 & 0 & 8 & 0 \\
\hline & $\begin{array}{c}\% \text { of people who reported } \\
\text { an accident }\end{array}$ & 1,42 & 0,23 & 0 & 2,39 & 0 & 0,88 & Variable \\
\hline \multirow[t]{3}{*}{2012} & Number of employees & 70 & 401 & 11 & 242 & 179 & 903 & Variable \\
\hline & $\begin{array}{c}\text { Reported occupational } \\
\text { exposures }\end{array}$ & 0 & 1 & 0 & 12 & 1 & 14 & 3 \\
\hline & $\begin{array}{c}\% \text { of people who reported } \\
\text { an accident }\end{array}$ & 0 & 0,24 & 0 & 4,95 & 0,55 & 1,55 & Variable \\
\hline \multirow[t]{3}{*}{2013} & Number of employees & 75 & 315 & 11 & 244 & 175 & 820 & Variable \\
\hline & $\begin{array}{c}\text { Reported occupational } \\
\text { exposures }\end{array}$ & 0 & 8 & 0 & 12 & 2 & 22 & 0 \\
\hline & $\begin{array}{c}\% \text { of people who reported } \\
\text { an accident }\end{array}$ & 0 & 2,53 & 0 & 4,91 & 1,14 & 2,68 & Variable \\
\hline \multirow[t]{3}{*}{2014} & Number of employees & 73 & 220 & 13 & 273 & 190 & 769 & Variable \\
\hline & $\begin{array}{c}\text { Reported occupational } \\
\text { exposures }\end{array}$ & 0 & 7 & 0 & 9 & 2 & 18 & 1 \\
\hline & $\begin{array}{c}\% \text { of people who reported } \\
\text { an accident }\end{array}$ & 0 & 3,18 & 0 & 3,29 & 1,05 & 2,34 & Variable \\
\hline \multirow[t]{3}{*}{2015} & Number of employees & 77 & 219 & 13 & 273 & 198 & 780 & Variable \\
\hline & $\begin{array}{c}\text { Reported occupational } \\
\text { exposures }\end{array}$ & 1 & 8 & 0 & 7 & 1 & 17 & 0 \\
\hline & $\begin{array}{c}\% \text { of people who reported } \\
\text { an accident }\end{array}$ & 1,29 & 3,65 & 0 & 2,56 & 0,50 & 2,17 & Variable \\
\hline \multirow[t]{3}{*}{2016} & Number of employees & 78 & 329 & 13 & 334 & 205 & 959 & Variable \\
\hline & $\begin{array}{l}\text { Reported occupational } \\
\text { exposures }\end{array}$ & 1 & 7 & 0 & 14 & 2 & 24 & 0 \\
\hline & $\begin{array}{l}\% \text { of people who reported } \\
\text { an accident }\end{array}$ & 1,28 & 2,12 & 0 & 4,19 & 0,97 & 2,50 & Variable \\
\hline
\end{tabular}

Analyzing the distribution of cases by department, it was found that surgery departments reported the most occupational exposures, followed by intensive care units and the medical departments (Figure 2).

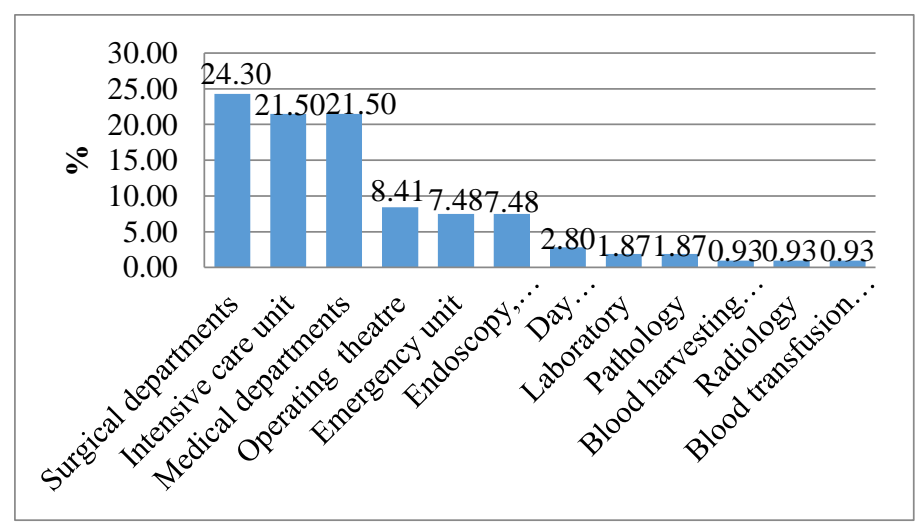

Figure 2. The burden of occupational exposures according to hospital departments in 2011-2016

Depending on age, the 25-29 years of age group reported $34 \%$ of the exposures, followed by 30-34, 35-39 and 40-44 years of age groups (with 19, 18 and 17\% respectively). It should be acknowledged that during the study period no occupational exposures to blood and other biological products was reported for the age group under 20 years or over 60 years of age. 
The analysis of gender distribution revealed a predominance of female gender of $88,97 \%$ in the report of these events.

Of the employees who reported exposure to biological products (107 cases), only 52\% stated they had a complete anti-hepatitis B vaccination strategy (Figure 3).

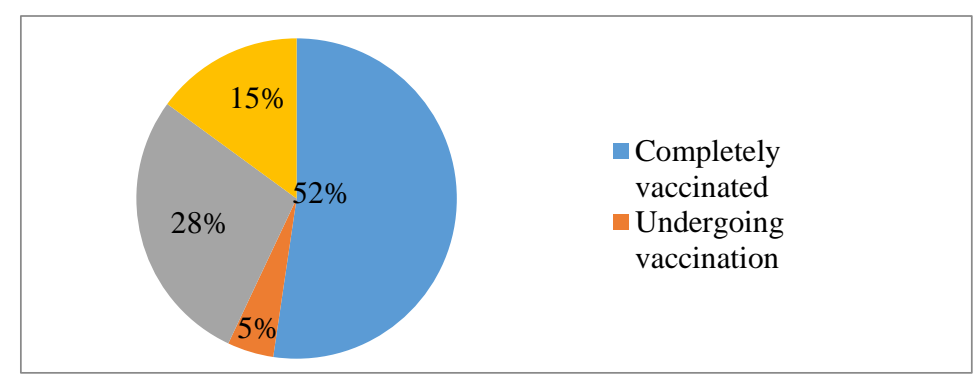

Figure 3. The vaccine status of the health care workers who reported an accidental exposure to biological products

Depending on the existence of an emergency situation at the time of the accident, 11 employees out of 107 said they had worked under pressure of an emergency event. Of those registered, 4 reported they had failed to perform the recommended post-exposure care. None of these (4 subjects) stated that exposure was due to emergency care of patients.

Most of the reported accidents were due to puncture with sharps (88 cases, i.e. $82,24 \%$ of all cases) and $10,28 \%$ were due to biological fluids projection.

The most commonly reported maneuvers as involved in the accidental exposures were blood harvesting in $26,17 \%$ of the cases, medical waste handling and i.v. (intravenous) treatment (in 9,35\%), and the insertion of a vascular catheter (peripheral or central) accounted for $8,41 \%$ of cases (table 2 ).

Table 2. The maneuvers that contributed to accidental exposures to blood and biological fluids

\begin{tabular}{|c|c|c|c|c|c|}
\hline Maneuver & $\begin{array}{c}\text { Number } \\
\text { of } \\
\text { reported } \\
\text { accidents }\end{array}$ & $\begin{array}{c}\text { \% of total } \\
\text { reported } \\
\text { accidents }\end{array}$ & Maneuver & $\begin{array}{c}\text { Number of } \\
\text { reported } \\
\text { accidents }\end{array}$ & $\begin{array}{c}\text { \% of total } \\
\text { reported } \\
\text { accidents }\end{array}$ \\
\hline Blood harvesting & 28 & 26,17 & Slicing anatomical parts & 2 & 1,87 \\
\hline Medical waste handling & 10 & 9,35 & Wound care & 2 & 1,87 \\
\hline Intravenous treatment & 10 & 9,35 & Housekeeping & 1 & 0,93 \\
\hline Insertion of vascular catheters & 9 & 8,41 & Blood group determination & 1 & 0,93 \\
\hline Removal of vascular catheters & 6 & 5,61 & Agitated patient care & 1 & 0,93 \\
\hline Reorganizing the working & 6 & 5,60 & Suture needle handling & 1 & 0,93 \\
\hline place & 5 & 4,67 & Trocar handling & 1 & 0,93 \\
\hline Needle recap & 4 & 3,74 & Measurement of intra-abdominal & 1 & 0,93 \\
\hline Surgery & 4 & 3,74 & Pressure & 1 & 0,93 \\
\hline Sharp object pick-up after use & 4 & 3,74 & Serum pipetting & 1 & 0,93 \\
\hline Surgical suture & 2 & 1,87 & Preparing the medication & 1 & 0,93 \\
\hline Upper endoscopy & 2 & 1,87 & Unknown & 2 & 1,87 \\
\hline Handling biopsy piece & 2 & 1,87 & Total & 107 & 100,00 \\
\hline Endoscope processing & & & & & 1 \\
\hline
\end{tabular}

Of the total number of exposures, in 83 cases wearing protective gloves would have been indicated. Only $80 \%$ of those exposed have respected the wearing gloves recommendation, at the accidental occupational exposure to biological products. In 13 situations it would have been advisable to wear the protective mask / protective glasses; only $61 \%$ of the exposed were using this additional protective measures.

In $15 \%$ of exposures, it was not possible to identify the source patient from whom the biologic product originated or the sharp device involved in the occupational accident was used. This situation 
required the follow up of the exposed persons for all the three viruses (HBV, HCV, HIV), according to the effective standard precautions, legislation, methodology and protocols.

The carrier/infected status of the patients was established for all identified sources, in the majority of cases the status was negative for all the three viruses of interest (Figure 4).

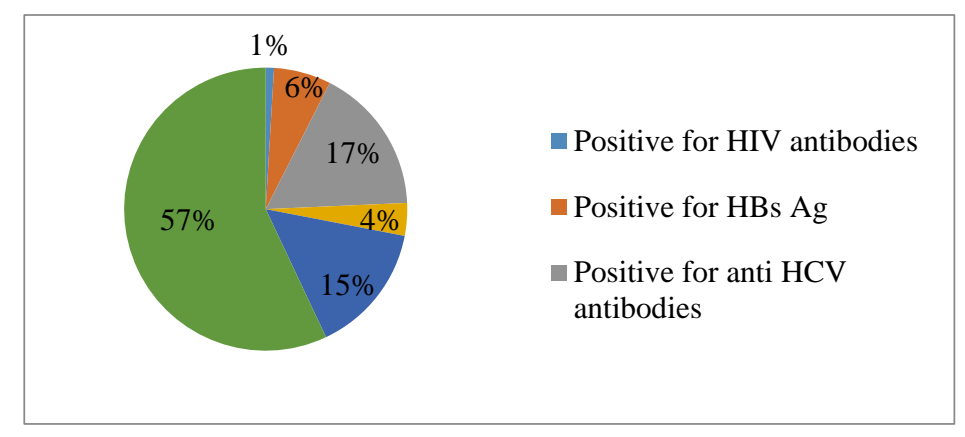

Figure 4. Serological status of the potentially infectious source

All injured employees (107 cases) were screened immediately after exposure and no carrier existing case was detected (HBV, HCV, HIV).

The compliance to post-exposure monitoring protocol of the exposed medical staff was assessed. Of 46 exposed persons, where the source was positive for at least one of the three viruses or the source was unidentifiable, only $23,91 \%$ have participated in all post-exposure monitoring tests; $19,57 \%$ omitted the first or second test, but came to the last examination; 17,39\% abandoned post-exposure tests after the first or second presentation and 39,13\% did not show up to any re-evaluation.

For those who followed the post-exposure monitoring strategy completely or who followed the plan only partially, but with a presentation at the last test, there was no case of seroconversion.

In the second part of the study, in group 1, out of 16 originally included persons (vaccinated or possibly vaccinated against hepatitis $B$ and who were exposed to biological products from HBV infected patients) in 3 cases it was not possible to determine the antibody titre due to lack of reagents, so they remained 13 in the group. By comparing them with the control group of 17 cases (vaccinated or possibly vaccinated against hepatitis B and who were exposed to biological products from patients free of HBV infection), the results of the Chi-square $(2 \times 2)$ test shows that there is no association between exposure to biological products and the presence of a protective titre $\left(\chi^{2}(1,30)=1.086, p=\right.$ 0.297).

During the study, the distribution of the number of accidental exposures per year was variable, with a slight increasing tendency as a result of the annual training of the staff employed in the facility [4]. However, there is a under-reporting if we compare the number of 107 exposures per 6 years with the average number of employees per year. A study in Saudi Arabia on a comparable number of employees recorded 326 exposures in 7 years. [12]

Of the professional categories, nurses reported the most exposures, in 2011 2,39\%, and in 2012 $4,95 \%$ of them reported an accident. Nurses represented a higher percentage in reporting accidental exposures in other similar studies [10-12]. This professional category is followed by resident doctors who reported the highest exposure rate $-3,65 \%$, in 2015. Laboratory staff with higher education (biologists, chemists), although they are handling biological products, reported no accidental exposure. Considering that the sanitary unit under study is a teaching clinic where the practical works (internships) of the students of the Faculty of General Medicine, of the Faculty of Nurses and of the various post-secondary health schools are held, the number of students is variable annually and for different periods of the same year, we have mentioned in the study a variable number of subjects. It should be specified that although they are not part of the stable staff of the hospital, they are required 
to adhere to all protocols and medical care procedures and good practice recommendations valid in the sanitary unit. The small number of students who have declared an exposure to a biological product can be explained by the fact that in the medical unit where the study was conducted the students in the fourth and the fifth year attend more theoretical and less practical activities, so that they do less medical maneuvers requiring the use of sharp, cutting medical devices.

The results of our study are discordant with those from a study in Korea, where 56,7\% of fourthyear students reported accidental exposure to biological products [2], or another study in Peru, where among sixth-year students who were asked to respond to a questionnaire, $85 \%$ recognized accidental exposure to biological products over the past year [8].

If in Cluj County during the period 2008-2012 most of the exposures were reported on the medical sections, at „Octavian Fodor Regional Institute of Gastroenterology-Hepatology” between 2011-2016, the surgical departments had a higher share, but were less registered in the operating rooms and the emergency unit [10].

Both in this study and in the one conducted by the same author in 2014 in Cluj County [10] or the one in Bosnia and Herzegovina [11], female gender prevailed. The fact that the high share of reports of accidental exposure to blood and other biological products was held by female gender is explained by the specificity of health care (nurses, caregivers and housekeeping personnel), female gender being predominant in the choice and the practice of these activities.

In the health unit where the study was conducted, the vaccine coverage with three doses of antihepatitis B vaccine of healthcare workers who reported occupational exposure to biological products, is only $52 \%$, although the World Health Organization recommendation, which locates the health care workers in risk category, indicates the vaccination of all those working in the medical field [20]. In our study, the vaccine coverage is comparable to that in Cluj County, 54\% [10] or Mangalore, India, $57,1 \%$ [13], but lower than the data from a study conducted in 120 Chinese hospitals, were the percentage of vaccinated employees with three doses was $60 \%$ [16].

In our study, as in a study in the United States [9], stinging exposure was the most common, and the most frequent incriminated maneuvers were blood harvesting, handling of medical stinging-cutting waste, administration of injectable treatment and vascular catheter assembly.

After testing the source patient, the HBV carriage was half of the one found in the study conducted in Saudi Arabia, but 26\% higher for HCV in the same study [12]. More frequent cases

with positive HCV sources can be explained by the highest chronic HCV infection rate [17], but also by the hepatology profile of the medical unit where this study was conducted, the addressability of patients with chronic hepatitis being different from other types of sanitary units.

At positive source exposure for at least one of the viruses, or where the source was unidentifiable (46 cases), the share of individuals who followed the complete post exposure testing program was very low, only $29,91 \%$. 39,13\% of the subjects did not show up to any subsequent testing, although they were notified of the test schedule and were also notified by phone call at the due date.

The highest non testing or abandonment of ongoing testing was for auxiliary staff (caregivers and housekeeping personnel). The lowest compliance with the post exposure monitoring protocol for this staff category could also be explained by the low level of health education and understanding the prophylactic actions that are specific to the health zone where they work.

For resident doctors, low compliance may be due to the fact that they have training modules in different departments/specialities, often in different medical units and returning for testing in the unit where they were exposed is more difficult.

When comparing the two groups under study, there was no association between exposure to biological products and the presence of an HBs antibody titre. The HBs Ab protective titre at the tested staff (30 cases), with a complete history of vaccination, was 79\% lower protector than in a tertiary hospital in India, where the presence of protective antibodies was 96,5\% [18] or in a healthcare workers group studied in Sri Lanka, where protection was 90.1\% [19] In our study, a proof of history 
vaccination against hepatitis B was not required in exposed individuals, with the possibility that some people may misread and in fact have not been vaccinated.

\section{Conclusions}

The health care workers included in the study underreport accidental exposures to biological products and also cooperation to track a possible seroconversion is low. There is a need for sustained awareness of the importance of the risk of transmitting pathogens from the patient to medical staff, actions to be carried out locally in healthcare facilities and through national information campaigns.

The hepatitis B vaccine coverage among medical staff is below ideal level. Is essential for the employer to provide the necessary hepatitis B vaccine doses when an unvaccinated person is employed.

The implementation of the use of as many sharp devices fitted with protective systems must be the concern of each sanitary unit.

\section{References}

1.MIR, O., ADAM, J., VEYRIE, N., CHOUSTERMAN, B., GAILlARD, R., GREGORY, T., YORDANOV, Y., BERVEILLER, P., LOULERGUE, P., „Accidental blood exposures among medical residents in Paris", France Clinical Microbiology and Infection, 17, no. 3, 2011, p. 464-6. DOI: 10.1111/j.1469-0691.2010.03321.x.

2.MOON, C.S., HWANG, J.H., LEE, C.S., PARK, K.H., KIM, E.S., „Exposure to blood and body fluid among medical students in Korea" American Journal of Infection Control, 38, no. 7, 2010, p. 582-3. DOI: 10.1016/j.ajic.2010.01.011.

3.***Centers for Disease Control and Prevention. „Workbook for designing, implementing, and evaluating a sharp injury prevention program, 2008", Available from: https://www.cdc.gov/sharpssafety/pdf/sharpsworkbook_2008.pdf

4.CHAILLOL, I., ECOCHARD, R., DENIS, M.A., IWAZ, J., KHOUEIRY, P., BERGERET, A., „Fast and specific detection of moderate long-term changes in occupational blood exposures", Occupational \& Environmental Medicine, 67, no. 11, 2010, p. 785-91. DOI: 10.1136/oem.2010.055699. Epub 2010 Aug 25.

5.PURO, V., DE CARLI, G., SEGATA, A., PICCINI, G., ARGENTERO, P.A., SIGNORINI, L., DAGlio, M., PENNA, C., MARCHEGIANO, P., MINIERO, M., CINTI, G., TAVANTI, L., MAGGIORE, A., SOSSAI, D., MICHELONI, G., „Giuseppe Ippolito Gruppo di Studio Italiano Rischio Occupazionale da HIV. Update on the subject of epidemiology of blood-transmitted occupational infections", Giornale Italiano de Medicina del Lavoro ed Ergonomia, 32, no. 3, 2010, p. 235-9.

6.LAVOIE, M.C., VERBEEK, J.H., PAHWA, M., „Devices for preventing percutaneous exposure injuries caused by needles in healthcare personnel", Cochrane Database of Systematic Reviews. 09 March 2014, DOI: 10.1002/14651858.CD009740.pub2

7.***MINISTERUL SĂNĂTĂŢII PUBLICE, „Ordin Nr. 916 din 27 iulie 2006 privind aprobarea Normelor de supraveghere, prevenire şi control al infecţiilor nosocomiale în unităţile sanitare", Monitorul Oficial no. 759, 06 september 2006

8.CHARCA-BENAVENTE, L.C., HUANCA-RUELAS, G.H., MORENO-LOAIZA, O., „Biological accidents in last-year medical students from three hospitals in Lima Peru”, Medwave, 16, no. 7, 2016, p. 6514 , DOI: $10.5867 /$ medwave.2016.07.6514

9.GREEN-McKENZIE, J., McCARTHY, R.B., SHOFER, F.S., „Characterisation of occupational blood and body fluid exposures beyond the Needlestick Safety and Prevention Act", Journal of Infection Prevention, 17, no. 5, 2016, p. 226-232. DOI: 10.1177/1757177416645339. Epub 2016 Apr 27.

10.KALMAN, E., MOISESCU-GOIA, M., DINU, E., BORZAN, C., „The study of production conditions and predisposing factors in the accident with exposure to biological products of healthcare 
personnel", Bulletin of the Transilvania University of Brasov, Series VI: Medical Sciences, 7, no. 56, 2014, p. 120-128.

11.JAHIC, R., PILJIC, D., POROBIC-JAHIC, H., CUSTOVIĆ, A., PETROVIC, J., PILJIC, D., „Epidemiological Characteristics of the Accidental Exposures to Blood-Borne Pathogens Among Workers in the Hospital", Medical Archives, 72, no. 3, 2018, p. 187-191. DOI: 10.5455/medarh.2018.72.187-191.

12.SAMARGANDY, S.A., BUKHARI, L.M., SAMARGANDY, S.A., BAHLAS, R.S., ALDIGS, E.K., ALAWI, M.A., AL-ABDULLAH, N.A., MADANI, T.A., „Epidemiology and clinical consequences of occupational exposure to blood and other body fluids in a university hospital in Saudi Arabia", Saudi Medical Journal, 37, no. 7, 2016, p. 783-90. DOI: 10.15537/smj.2016.7.14261.

13.KUMAR, H.N., NAMBIAR, R.P., MOHAPATRA, S., KHANNA, A., PRAVEEN, R., SAI BHAWANA, D., „A Cross-sectional Study on Hepatitis B Vaccination Status and Post-exposure Prophylaxis Practices Among Health Care Workers in Teaching Hospitals of Mangalore", Annals of Global Health, 81, no. 5, 2015, p. 664-8. DOI: 10.1016/j.aogh.2015.08.015.

14.QUAN, M., WANG, X., WU, H., YUAN, X., LEI, D., JIANG, Z., LI, L., „Influencing factors on use of standard precautions against occupational exposures to blood and body fluids among nurses in China", International Journal of Clinical and Experimental Medicine, 8, no. 12, 2015, p. 22450-9. eCollection 2015.

15.EGRO, F.M., NWAIWU, C.A., SMITH, S., HARPER, J.D., SPIESS, A.M., „Seroconversion rates among health care workers exposed to hepatitis $\mathrm{C}$ virus-contaminated body fluids: The University of Pittsburgh 13-year experience", American Journal of Infection Control, 45, no. 9, 2017, p. 1001-1005. DOI: 10.1016/j.ajic.2017.03.011. Epub 2017 Apr 24.

16.YUAN, Q., WANG, F., ZHENG, H., ZHANG, G., MIAO, N., SUN, X., WOODRING, J., CHAN, P.L., CUI, F. „Hepatitis B vaccination coverage among health care workers in China”, PLoS One, 14, no. 5, 2019. DOI: 10.1371/journal.pone.0216598. eCollection 2019.

17.***WORLD HEALTH ORGANIZATION, „Hepatitis C”, 2019, Available from: https://www.who.int/en/news-room/fact-sheets/detail/hepatitis-c

18.BASIREDDY, P., AVILELI, S., BELDONO, N., GUNDELA, S.L., „Evaluation of immune response to hepatitis B vaccine in healthcare workers at a tertiary care hospital", Indian Journal of Medical Microbiology, 36, no. 3, 2018, p. 397-400. DOI: 10.4103/ijmm.IJMM_17_431.

19.CHATHURANGA, L.S., NOORDEEN, F., ABEYKOON, A.M., „Immune response to hepatitis B vaccine in a group of health care workers in Sri Lanka", International Journal of Infectious Diseases, 17, no. 11, 2013, p. e1078-9. DOI: 10.1016/j.ijid.2013.04.009. Epub 2013 Jun 28.

20.***WORLD HEALTH ORGANIZATION, „Weekly Epidemiological Record”, 92, no. 27, 2017, p. 369-392, Available from: https://apps.who.int/iris/bitstream/handle /10665/255841/WER9227. pdf? Sequence $=1$

Manuscript received: 24.11 .2020 